\title{
Conceptualising Smart City for the Development of Nigeria's Urban Transportation
}

\author{
AJALA, Abdul-Rahman T. \\ Department of Transportation Planning and Management \\ Federal Polytechnic \\ Ilaro, Ogun State \\ E-Mail: taiwoajala2014@gmail.com \\ Mobile: 08034858513,
}

\begin{abstract}
Smart city concept is recent but well studied, its definition is as much as the number of field of studies, though it is first conceptualised as an ICT solution to city challenges but today, it is well extended to every aspect of urban management. This paper examines the concept as a development approach to city challenges and reviews one of its domain 'smart mobility' in the light of transportation challenges in Nigerian cities. It is discovered that application of the concept in Nigeria will be limited by the level of ICT infrastructure, absent of a national policy guideline and poor investment in transport infrastructure. The paper recommends development of a national guideline for integrated transport development; establishment of a city structure that will coordinate and promote investment with innovative funding that will support ICT-infrastructure in the transport sector.
\end{abstract}

Keywords: Smart city, smart mobility, transportation, development, urban liveability

Aims Research Journal Reference Format:

Ajala, Abdul-Rahman T. (2018): Conceptualising Smart City for the Development of Nigeria's Urban Transportation. Advances in Multidisciplinary \& Scientific Research Journal. Vol. 4. No.2, Pp 65-72

\section{INTRODUCTION}

City efficiency and development cannot be separated from effective transport system, which integrates different spatial elements of the city into a functional entity. As city grows, the spatial challenges increases especially that of bridging the geographical gaps between locations. Transportation, therefore, is an important service that supports city sustainability and liveability. Like any other African countries, the growth of Nigerians' cities is well acknowledged in the literature. United Nations once predicted that by $\mathbf{2 0 3 0}$ more people will live in cities than in the rural area, this prediction does not exclude African continent. African countries are expected to have 61.8 percent increase in urban population (UN-Habitat, 2010).

Nigeria has its own share of the urbanisation with the increased growth rate of urban population over the years the rate is estimated to grown from about $17 \%$ in 2006 to $49.4 \%$ in 2016, thus bringing the number of cities with over 1 million population to about nine (Badejo,2014). Without hesitation, the rapid growth greatly brought about enormous challenges in many towns and cities, especially, inadequate and poor public transportation. The demand for transportation has not been met with supply, rather traffic congestion, pollution and social inequalities are the reflection of the city mobility.

Efficient transport system has become apparently needful for city survival and liveliness particularly in today's society when most city dwellers lose productive hours on road and also with some health challenges brought about by pollutants emitted into the atmosphere by the increased use of automobile. This paper focuses on the reviewing of smart city conception as an ideal approach to transportation transformation (development) in Nigeria.

The study through literature search presents the conceptual definition of smart city and x-ray the factors or elements of city smartness in the second and third section of the paper. A review of transportation challenges in Nigerians cities with focus on Lagos state was undertaken in the fourth section of the paper. The fifth and the last sections present the global experience from San Francisco and conclude with policy implications of smart city concept for Nigeria transport development. 


\subsection{Concept and Definition of Smart City}

The term "Smart City" is a combination of two words "Smart" and "City". Literarily, smart is a human attribute that express as the degree of response to impulses by man, it characterizes the intelligence to sense and response to challenges by man. City on the other hand is a geographical entity inhabited by human being; it is a centre of socio-economic activities with multi-dimensional services. Cities are urban areas with high population concentration relative to town and village; it is a multi-functional entity that provides variety of services for the citizens, such as transportation. The growth in city population all over the world has placed a demand on the infrastructure and services provided by the city. The ability of the city to respond to this demand can make or mar the city. Smart City therefore can be defined as city with ability to sense and respond to its challenges using intelligence embedded in the city's information system (Ramaprasad, et al, 2017).

Between 1990's and now that smart city became prominent, the concept has attracted much attention from the academia and professional, such that there are many definitions as different field of study. Earlier definitions of the concept were focused on the use of information and communication technology in the management of city function (Lombardii et al, 2012), these were criticised on the ground that if smartness of a city is solely considered on improving technological system, that can become obsolete, city will not be sustainable on the long run (Murgante \& Borruso, 2015). Hence the concept was expanded to capture the product or the goal of smart city which is improvement of the quality of lives of city dwellers among other things. Therefore these two definitions were examined:

"An urban ecosystem that places emphasis on the use of digital technology, shared knowledge and cohesive processes to underpin citizen benefits in vectors such as mobility, public safety, health and productivity" (Juniper Research, 2017)

"As an integrated system in which human and social capital interact, using technology-based solutions. With the aim of achieving efficiency, sustainable and resilient development and a high quality of life based on multi stakeholder and municipality partnership".(Monzon, 2015)

From the above definition, it is clear that smart city is multi-disciplinary concepts that transient information technology input, though, technology is the enabler because ICT-based solutions are the key element. The capacity to manage the overall city resources to achieve efficient, sustainable development, and high quality of life is very paramount. Smart city therefore represent innovations in city services and infrastructural management that bring about efficient service delivery that will in turn impact on prosperity and quality of life of its inhabitants.

\section{CITIES AND FACTORS OF SMARTNESS}

A well-managed city is a potential generator of economic growth, because it enjoys economy of scale as a centre for both production and consumption, trade with specialised functions and linkages to surrounding rural areas (Oyesiku, 2010). The largest percentage of the world GDP accumulates from cities, hence it is a focal point in regional development (Cohen, 2006). Cities are organic in nature; they grows in size and magnitude with attendant negative impacts such as pollution, traffic congestion, crime and other social inequality. However, smart city approach offers a better city planning and management that ensure sustainable city growth.

A literature search shows that scholars have (Caragliu et al, 2011 and Albina et al, 2015) identified some characteristic elements of a smart city, and these include; Network of infrastructure; Social inclusion; environmental sustainability; and business-led urban development. Further to this Gittinger et al (2007) consider six characteristics as framework on which smart city can be conceived, these include smart economic, smart mobility, smart environment, smart governance, smart people and smart living. Similarly, Neirotti et al (2014) also group the key elements into six; natural resources and energy; Transport and mobility; buildings; living; government; economy and people.

Contrary to the view of Gittinger et al (2007) and Neirotti et al (2014) who identified six key elements, Lombardii et al (2012) identified five categories of elements as including Smart governance, Smart human capital, Smart environment, Smart living and Smart economy. likewise Chourabi et al (2012) who took interest in the external and internal factors as well as sustainability and liveability goal of smart city, he considered eight fundamental factors which include; management and organization, technology, governance, policy, people and community, the economy, built infrastructure, and the natural environment. From their submissions, the categorization of elements is but similar with slight regrouping which may be a reflection of individual bias or interest. However, consideration of built infrastructure especially mobility appears to be considered by five out of six group of the researchers as shown in table 1 below. 
Table 1 Summary of Smart City Factors/Elements in the literature

\begin{tabular}{lll}
\hline $\begin{array}{l}\text { Caragliu et al (2011) } \\
\text { Albina et al (2015) }\end{array}$ & Gillinger et al (2007) & Neirotti et al (2014) \\
\hline Social inclusion & Smart economy & Natural resources and energy \\
Environmental sustainability & Smart governance & Building \\
Business-led urban development & Smart environment & Transport and mobility \\
Network of infrastructure & Smart living & Living \\
& Smart mobility & Government \\
& Smart people & Economy and people \\
\hline Lombardit et al (2012) & & \\
\hline Smart economy & Chourabi et al (2012) & Junipa Research (2017) \\
Smart human capital & Management and organisation & Public safety \\
Smart environment & Technology & Health \\
Smart living & Governance & Productivity \\
Smart governance & Policy & Mobility \\
& People and community & \\
& The economy & \\
\hline
\end{tabular}

Juniper Research (2017) in a research to reveal measurable time saving to citizens of smart cities across the globe, assessed all smart cities of the world using four factors which reflected in the definition of smart city earlier alluded to (mobility, public safety, health and productivity). Table 2 presents the ranking of cities globally based on the consolidated performance having Singapore as the smartest city. The Table also present the ranking using the mobility index, San Francisco is ranked second as against its fourth position in the general assessment. Hence city smartness could vary in different areas of interest or the challenges it's tries to address.

Table 2, Present Top 20 Smart Cities Globally.

\begin{tabular}{|c|c|c|}
\hline Rank & Smart City & Smart mobility \\
\hline 1 & Singapore & Singapore \\
\hline 2 & London & San Francisco \\
\hline 3 & New York & London \\
\hline 4 & San Francisco & New York \\
\hline 5 & Chicago & Barcelona \\
\hline 6 & Seoul & Berlin \\
\hline 7 & Berlin & Chicago \\
\hline 8 & Tokyo & Portland \\
\hline 9 & Barcelona & Tokyo \\
\hline 10 & Melbourne & Melbourne \\
\hline 11 & Dubai & San Diego \\
\hline 12 & Portland & Seoul \\
\hline 13 & Nice & Nice \\
\hline 14 & San Diego & Dubai \\
\hline 15 & Rio de Janeiro & Mexico City \\
\hline 16 & Mexico City & Wuxi \\
\hline 17 & Wuxi & Rio de Janeiro \\
\hline 18 & Yinchuan & Yinchuan \\
\hline 19 & Bhubaneswar & Hangzhou \\
\hline 20 & Hangzhou & Bhubaneswar \\
\hline
\end{tabular}




\section{MOBILITY PROBLEMS OF NIGERIAN CITIES}

Transport and mobility has been identified as a key factor in the determination of smartness of a city. This point to the role played by transportation in the production and distribution of city services. Cities perform their functions as centres of socio-political interaction, economic activities and human capital development efficiently and effectively when the transport system is sound. Hence, the mobility challenge is one core area the smart city initiative has come to address.

Nigerian cities like in any other third world countries are facing demographic pressure and rapid urbanization. There is a geometric increase in the population without corresponding development in infrastructure, thus giving rise to complaints about overcrowding and infrastructural decadence. United Nations, in 2016 estimated that $54.5 \%$ of the world's population lived in cities and by 2050 the number will increase to $67 \%$, this invariably will increase demand for movement of goods and services.

As a way of meeting the demand for movement within the Nigerian cities, there is massive supply of transport services through the unconventional modes i.e. mini buses, private cars, motorcycles and three wheelers. The car ownership rate has tremendously increased as a symbol of personal freedom from inefficient public transit coupled with over reliance on road mode which reflects in the policy and planning of urban mobility in the country (Badejo, 2011). All of these have created massive pressure on the road infrastructure, resulting in traffic gridlock, congestion and delay with the attendant effects on the volume of pollutant emitted into the atmosphere. Traffic congestion and air pollution are serious challenges facing cities in Nigeria.

A focus on Lagos city as a case study of Nigerian city mobility challenges presents a myriad of problems including incessant traffic congestion; infrastructural inadequacy; poor service delivery; poor connectivity; unregulated fare regime; dominance of informal sector in the provision of transport service; very high car ridership and poor traffic management (Badejo, (2014B); Oladehinde, (2018) and Ajala, (2016). Putting these in perspective, the congestion pattern in Lagos as at 2016 present an average speed of $17-18 \mathrm{~km} / \mathrm{h}$ in all direction, this situation if unabated is estimated to slow down to $9 \mathrm{~km} / \mathrm{h}$ by 2032 (Oladehinde, 2018) a situation that will make travelling within Lagos a difficult task and socio-economy activities may be near a standstill situation.

Increased travel demand from a population of about 22 million (Oladehinde, 2018) in itself is a challenge to the city of Lagos, in the face of a single public transit mode (road) coping with over 28 million trips (table 2) that will be generated on daily basis in Lagos by 2032 will also affect liveability of the city, hence the future mobility challenge of Lagos mega cities.

Table 2: Future Trip Generation by Model Cities in Lagos State 2032

\begin{tabular}{|c|l|l|c|}
\hline $\mathbf{S} / \mathbf{N}$ & Model City & Trips Generated & \% of trips \\
\hline 1 & Alimosho & $3,241,576$ & $11 \%$ \\
\hline 2 & Agege/lfako & $2,127,439$ & $7 \%$ \\
\hline 3 & Apapa & $1,352,328$ & $5 \%$ \\
\hline 4 & Badagry & $2,930,197$ & $10 \%$ \\
\hline 5 & Ikeja & $2,374,400$ & $8 \%$ \\
\hline 6 & Lekki & $2,641,307$ & $9 \%$ \\
\hline 7 & Mainland Central & $7,065,975$ & $25 \%$ \\
\hline 8 & Victoria Island/lkoyi & $2,519,758$ & $9 \%$ \\
\hline 9 & Ogun State (pressure areas) & $3,055,757$ & $11 \%$ \\
\hline 10 & Ikorodu (in view) & $1,445,676$ & $\mathbf{1 0 0} \%$ \\
\hline Total & & $\mathbf{2 8 , 7 5 4 , 4 1 3}$ & \\
\hline
\end{tabular}

Source: Oladehinde, 2018 
Lack of connectivity that can promote inter-modality and multimodal system is evident in total collapse of road infrastructural facilities, the stress imposed on road transport infrastructure is as a result of the dominant role it plays in city mobility, about $90 \%$ of both passenger and freight are accounted for by road mode which is in sharp contrast to its comparative advantage (Badejo, 2011). Badejo, also noted that with the exception of Port Harcourt and Apapa port, Nigeria ports have no rail nor waterways connection, railways operates a solitary system as an interstate transport mode until recently when the Lagos state initiated the Lagos light rail for urban mobility which is yet to be completed. Rather than the modes been integrated there exist a stiff competition which is a reflection of a lopsided or none existing policy. No doubt all of these affect productivity, environmental quality, travel time, operating cost and general well-being of the people. Hence there is a demand for smart mobility that will bring about efficient, effective and more sustainable cities.

\section{GLOBAL SMART CITIES EXPERIENCE: APPLICATION AND CHALLENGES}

According to Juniper Research, (2017) San Francisco is the globally ranked second in smart mobility, the city mobility challenge were high vehicle ownership and congestion such that drivers in the city waste 150 hours every year in traffic. Having realized the effect on the efficiency of the city, the following mobility strategies were developed:

i. Integrated and shared mobility: this is based on technology platform that support integrated service which allow citizens to choose from a range of modal options. It also includes a customer solution that provides a single or integrated platform for pricing, routing, booking and payment. The goal of this is to provide every citizen the opportunity to plan his journey within the public transport system and obtain the best quality of service within shortest possible time (reduction in travel time).

ii. Shared Autonomous Vehicles: this is to provide an alternative to private car ridership through the on-demand service vehicle that provides multi-occupancy riders. This equally includes vehicle-infrastructure interface that determines optimal traffic light phasing according to real-time condition. The benefits of this strategy include lower congestion, improved air quality, lower travel costs and reduced traffic fatalities.

The San Francisco experience point to the fact that smart mobility is based on the multi-modal integration, that brings under the same platform the transport infrastructure, services and the commuters. The place of technology as the enabler for the integration is evident and important. However, Smart mobility index has been identified to include: efficient Public transport; ICT infrastructure; Multimodality; Clean, non-motorised option; logistics; Traffic management; accessibility and Inclusiveness.

Efficient public transport system is based on inter-modality, where all modes will be developed to provide services in a complimentary form. Emphasis need be shifted from road as a domineering mode. This need be reflected in infrastructure development, operations, and pricing. The challenges here is that of the monopoly of NRC in the provision of railway services in Nigeria, and the numerous unregulated operators and their unions in the road transport sub-sector. Another challenge is the numerous regulatory agencies managing public transport in city, such as inland waterways authority, Ministry of Transport; Nigeria Railways Corporations, these agencies do not have a good synergy on developing an integrated transport system. However, the long awaited transport policy that should provide a framework for their coordination remain a draft for almost three decades (Ajala, 2016)

The backbone of an integrated transport service is the information technology, it influences the operations of the public transport system through integrated pricing, routing/transit scheduling, booking and payment. This provides the platform that enables commuters to access transport service from their device such as cell phone. Nigeria cities are still far from the ICT infrastructure, and innovations that will transform the cities into a technology based society. Equally the smart energy that will support the ICT -infrastructure has not been developed to the level of complimenting the system. 


\section{POLICY DIRECTION FOR NIGERIA TRANSPORT DEVELOPMENT}

Research has found that access to smart mobility is limited by factors such ICT infrastructure and policy guideline, these two being central to development of transportation in Nigeria. No doubt, the degree of responsiveness of the city to socio-economic development and environmental sustainability and livability depend on physical and legislation infrastructure available to support meaningful development in any aspect of urban development. Also limited human capital and economic resources with increased level of poverty are also hindrance to smart mobility (Mircea et al, 2017)

In the light of the fact that there is lofty need for effective, efficient and sustainable smart mobility in Nigerian cities the policy direction must focus on the following key areas:

i. Development of a national guideline for transport development with emphasis on integrated infrastructure, operations, ticketing/payment, and commuters' information. This will be aimed at bringing the urban public transport on a single platform where each mode will complement each other and thereby promoting public transport over the private car use.

ii. Establishment of a city structure that will coordinate and promote investment in transport development. The structure that will bring all modes under the same platform for planning, design, implementation and review of city transport plan. Example of such structure is the Lagos Metropolitan Transport Authority (LAMATA).

iii. Building integrated transport infrastructure requires significant investment, which may be too burdensome to government, hence, investment options based on public private partnership and other innovative funding and financing approaches should be given adequate consideration.

iv. Investment in ICT-infrastructure and innovations that promote public transport with Smart energy should be part of transport development. If ICT-infrastructure is the enabler to smart mobility and the ingredient are the smart energy, smart economy, and smart people. Holistic development of ICT with respect to the entire element must be given concern with people at the centre.

\section{CONCLUSION}

Transportation development has not been given holistic approach in the country for years, this paper has identified the lopsided development in favor of road transport and the attendant pressure on the existing road system of which the effect characterized the cities system. The result had been traffic congestion resulting from very high car ridership; infrastructural inadequacy; poor service delivery; poor connectivity; unregulated fare regime; dominance of informal sector in the provision of transport service; and poor traffic management. The ability of city to response to these challenges has been addressed in the paper using Smart city concept and the factors of smart mobility domain. Four areas of transport development has also been identified for policy makers to realign focus on many aspects of city elements such as: Development of a national guideline for integrated transport development; Establishment of a city structure that will coordinate and promote investment; employ investment options based on public private partnership and other innovative funding and financing approaches; and Investment in ICT-infrastructure and innovations.

\section{DIRECTION FOR FUTURE WORK}

Smart mobility has not been adequately studied in this part of the world, especially on how it can be used to solve urban traffic congestion and delay, hence further work on improving urban mobility may include Application of ICT-Infrastructure for efficient traffic management and reduction in traffic infractions. And most importantly, transport data collection, storage and retrieval for smart mobility. 


\section{REFERENCES}

1. Ajala, A. T. (2016). Traffic management strategies and best practices. Abeokuta, Ogun State: Gbenga Gbesan and Associates.

2. Albino, V., Berardi, U., \& Dangelico, R. M. (2015). Smart cities: definitions, dimensions, performance, and initiatives. Journal of Urban Technologist, 22, $3-21$.

3. Badejo, B. A. (2011). Transportation removing the clogs to Nigeria's development. Lagos, Nigeria: Anchorage Press \& Publishers.

4. Badejo, B. A. (2014). Transporting the future today: Portrait of Nigeria. 65th Inaugural Lecture, Olabisi Onabanjo University, Ago-iwoye, Ogun State, Nigeria.

5. Badejo, B. A. (2014). Road safety and Nigeria development: The urgency of now. 3rd Waheed Kadiri Annual Lecture 2014, Nigerian Association of Town Planning Students, Moshood Abiola Polytechnic, Abeokuta Chapter. Abeokuta, Ogun State.

6. Caragliu, A., Del Bo, C., \& Nijkamp, P. (2011). Smart cities in Europe. Journal of Urban Technol., 18, 65 - 82.

7. Cohen, B. (2006). Urbanization in developing countries: current trends, future projections, and key challenges for sustainability. Technol. Soc. 28, $63-80$.

8. Chourabi, H., Nam, T., Walker, S., Gil-Garcia, J. R., Mellouli, S., Nahon, K., Pardo, T. A., \& Scholl, H.J. (2012). Understanding smart cities: An integrative framework. Presented at 45th Hawaii International Conference on System Science (HICSS), pp. 2289 - 2297. IEEE

9. Gittinger, R., Fertner, C., Kramar, H., Kalasek, R., Pichler-Milanovic, N., \& Meijers, E. (2007). Ranking of European medium-sized cities. Final Report, Centre of Regional Science, Vienna, UT.

10. Juniper Research (2017). Smart cities - what's in it for citizen? A study of smart cities across the globe. Juniper Research and Intel. Retrieved from www.juniperreseach.com

11. Lombardi, P., Giordano, S., Farough, H., \& Yousef, W. (2012). Modelling the city performance. Innovative European Journal of Social Science Research, 25, $137-149$.

12. Mircea et al. (2017). Smart city concept in 21st century. 10th international conference interdisciplinarity in engineering INTER-ENG 2016, Procedia Engineering 181, pp 12 - 19. Retrieved from www.sciencedirect.com.

13. Murgante, B. \& Borruso, G. (2015). Cities and smartness: the true challenge. International journal of Agricultural environment. Inf. Syst., 6(5)

14. Monzon, A. (2015). Smart cities concept and challenges: Bases for the assessment of smart city projects. Springer International Publishing Switzerland, pp. 20.

15. Neirotti, P., De Marco, A., Cagliano, A.C., Mangano, G., \& Scorrano, F. (2014). Current trends in smart city initiatives: some stylised facts. Cities, 38, $25-36$.

16. Oladehinde, F. (2018). The Lagos state strategic transport master plan. A paper presented to students of Transportation Planning and Management, Federal Polytechnic, Ilaro at LAMATA Hq. Ojota, Lagos.

17. Oyesiku, K. (2010). New Cities in Urban and Regional Development Planning. Ikeja, Lagos: Longman Nigeria Plc.

18. Ramaprasad, A., Sanchez-Ortiz, A. \& Syn. T. (2017). A unified definition of a smart city. International Federation for Information Processing IFIP, Springer International Publishing AG. pp $13-24$.

19. UN-Habitat (2010). The state of African cities 2010 Governance: Inequality and urban land market, Nairobi. Retrieved from www.unhabitat.org 535.eng.ed 2010 


\section{APPENDIX}

\section{Definition of Terms}

* City: City is an urban area with large population. It is a geographical entity where secondary and tertiary services could be accessed.

* Mobility: Effective movement of people and goods with reference to travel time, distance, and cost. It is use for measuring transport system performance

* Transportation: The means of conveying people and goods from one location to the other, through various modes which include air, rail, road, cable, water and pipeline.

* Development: Is the improvement in the welfare of a society through appropriate programme and policy on socio-economic and political condition.

* Urban Liveability: is defined as development of safe, reliable, economical convenient and environmentally friendly urban system that promotes public health. 